\title{
Spatial and Temporal Analysis of Natural Drainage in the Ressacada Aquifer (Florianopolis, Brazil)
}

\author{
Fabrizio Rama, Davide Franco, and Henry X. Corseuil
}

\begin{abstract}
This paper proposes an in-depth statistical exploration of the available hydraulic head data concerning the Ressacada aquifer (Florianopolis, Brazil). By means of this approach, the study aims to obtain a complete picture of the natural drainage in the domain. This intent supports the understanding of the relationship between rainfalls and aquifer level fluctuations in this coastal region. In a broader perspective, the drainage term can be used in the application of the water table fluctuation method, in order to explain the seepage behavior and recharge phenomena. The chosen study area was a shallow coastal aquifer surrounded by mangrove swamp in a humid subtropical climate region. In view of the cited features, it represented a complex domain to assess both groundwater and surface processes. Besides, the co-occurrence of numerous anthropogenic factors, and the presence of strategic interest areas (International Airport, Military base camp), have further complicated the vertical infiltration and the natural drainage. Finally, results showed two main groups of piezometers with a typical drainage behavior. It seems to depend on the well position in the flow field and, therefore, on the distance from surface receptors. In each group, two distinct drainage conditions were also detached in terms of the water table level.
\end{abstract}

Index Terms-Natural drainage, spatial analysis, coastal aquifer, water table fluctuation method.

\section{INTRODUCTION}

More and more studies in the last two decades have observed the importance of the hydraulic head records in order to understand hydrodynamics of groundwater. The relationship between natural forcing (e.g. rainfalls and tidal oscillations) and water level fluctuations in the aquifer is of primary importance to explain in an effective way the flow field, especially in shallow aquifers [1], and more specific in all unconfined coastal aquifers rounded with oscillating head conditions and characterized with a scarce water table depth or an intense reactivity to changing conditions [2], [3]. The

Manuscript received May 30, 2017; revised July 20, 2017. This work is part of a research and development project in partnership UFSC/FEESC/Petróleo Brasileiro (Petrobras): Additions and improvements in the SCBR (Risk-Based Corrective Solution) mathematical model to support environmental management of Oil\&Gas contaminated areas (Contract number: 0050.0096599.15.9).

Fabrizio Rama is with the Núcleo Ressacada de pesquisa em meio ambiente (REMA), Department of Environmental Engineering, Federal University of Santa Catarina (UFSC), Florianopolis, SC, 88040-900 Brazil (e-mail: fabrizio.rama@posgrad.ufsc.br).

Davide Franco is with Laboratório de Hidráulica Marítima (LAHIMAR), Department of Environmental Engineering (UFSC), Brazil (e-mail: franco@ens.ufsc.br).

Henry X. Corseuil is with Núcleo Ressacada de pesquisa em meio ambiente (REMA), Department of Environmental Engineering (UFSC), Brazil (e-mail: henry.corseuil@ufsc.br). task becomes even more challenging in extreme climate and environmental conditions, on the southern cost of Brazil, where strong and varying precipitations in the presence of dense mangrove areas would modify the response of groundwater system [4], [5]. In the described situation, continuous monitoring of the water table could be used both to predict future fluctuations and to establish the recharge of the aquifer [6]: the results obtained so far support its use in different types of technical applications and in different scientific areas [7], [8]. Nevertheless, generally speaking already available datasets include only discrete measurements of water heads, scattered and irregularly spaced in time. This kind of data, although rarely used, can be a useful source for information and prediction about aquifers if properly mined and processed.

For this reason, among the different methods available in literature, the water table fluctuations (WTF) method was chosen since it provides a valuable tool for interpreting hydraulic head fluctuations over a wide variety of climatic conditions and different time-scales [9]. Despite the flexibility of the method, different limits for its application have been reported in the literature [10] linked to a variety of factors: long-lasting and light rains (due to underestimation of the recharge), daily or weekly fluctuations of the recharge, sampling interval of the hydraulic loads, difficulties in estimating the specific storage and natural decrease rate of the water table. Focusing on the last point, [11] deals with it through an automatic method that estimates the descent at each moment (MRC), while another study [12], defines the drainage rate (D), as a constant for the entire time and domain, maintaining a statistical approach to estimate its value. In both works a robust and data-driven choice on the drainage term stands out as an important aspect.

For this reason, the present study aims to analyze and estimate, in a clear and objective way, the decreasing rates of water table levels (all drainage contributes) in the Ressacada aquifer, located in Florianopolis island. Furthering this topic is of great importance for the accurate application of WTF method with a discrete time series approach. The aquifer of the case study is a shallow coastal system located in humid subtropical climate, close to mangrove swamps and a complex estuarine system subject to tides. The paper is based on the exploratory analysis of the water table historical series collected at the Experimental Farm of Ressacada. The possible differences in local response to precipitations (spatial variation) were also investigated by comparing piezometers data in a region considered geologically uniform. The study enhances the knowledge of groundwater dynamics in the area and contributes to design the domain conceptual model, analyzing and reliably defining the drainage termfrom a statistical point of view. Furthermore, this allows the 
application of the WTF method to estimate recharge, corrected with the addition of the drainage contributions.

\section{MATERIALS AND MethodS}

The case study is a phreatic aquifer located in the Experimental Farm area of Ressacada, owned by the Federal University of Santa Catarina (UFSC) in the southwest region of Santa Catarina Island, Florianopolis. The whole peninsula is characterized by a flat estuarine system: natural slope between 0 and $3 \%$ (excluding trenches and anthropogenic dams), and topography between -0.1 and 4.9 meters above sea level. From a geological point of view, the region is fairly uniform and presents lacustrine deposits with predominance of quartz fine sand with lenses of silt and clay (in general 5-15\%), with two main features: a "Intertidal Plain" in the main central part of area and a "Tide Plain" in the boundaries near the shoreline characterized by mangrove swamps [13]. Field studies performed in the farm shown that the soils are characterized by an average total porosity of $36.8 \%$ (3\% deviation), also with high values of moisture (20-25\%) and saturation percentage in the vadose zone above the static level [14]. In accordance with the description, the aquifer is a costal shallow system: mean depth of 30-40 m and water table within $0.3-2 \mathrm{~m}$ to surface, with a very low natural gradient, hydraulically connected to the Tavares River Basin (the second most important on the island) and exposed to intense periodic fluctuations of water levels. It is drained at its boundaries by the South Bay and the Tavares River and at its center by a set of artificial channels, which help to maintain the water table below the topographic surface. The groundwater flow of the study area occurs mainly towards NW-SE, and the natural discharge of aquifer flows to the channels and to the left bank of Tavares River (Fig. 1).

Meteorologically, the island is defined as humid subtropical climate in the Köppen-Geiger climate classification [15]. Normal rainfall rates varies between 1200 and $1600 \mathrm{~mm}$ per year with higher amounts in the months of January to March, and lower between June and August. The rains have an impulsive character with high intensity and outstanding variability. In addition to this common variability, the impacts of periodic precipitation anomalies linked to Southern Oscillation (also known as El Niño and La Niña), are more pronounced than in Argentina and Uruguay [16]. The rainfall data included in the study refer to daily accumulations (24h on Brasilia local time) and were provided by the Institute of Airspace Control (Ministry of Defense). The station is part of the METAR and WMO network (83899) and is located at Florianopolis Airport ( $27^{\circ} 40^{\prime} 14$ "S - $48^{\circ}$ $32^{\prime} 50^{\prime \prime} \mathrm{W}$ ) less than 400 meters from the experimental areas. To consolidate this temporal rainfall series, two other datasets were also consulted: an hourly-based dataset from the INMET automatic station in Florianopolis-São José (WMO: 86958), $2 \mathrm{Km}$ away from the first station and the database of the pluviometric control of Ressacada Farm, that was supplied by the technicians of Agrarian Sciences Center (CCA).

For the purposes of the present work, data from 13 piezometers were used, in the time window from 2007 to 2016. All the piezometers are located in experimental area 3 in the Ressacada Farm. Table I presents design information for included ones. Most of piezometers are shallow and intercept phreatic aquifer up to a depth of $4.5 \mathrm{~m}$, except for PZ01, PZ02 and PE06, which reaches respectively 15, 10 and $30 \mathrm{~m}$ of depth. The sample intervals are discontinuous and variable in time - from 1 to 60 days in the summer closure and per each sample location. Therefore, the influence of all phenomena with subdaily signal frequencies (like local astronomical tides, small earthquakes, and Lisse effects) was omitted and will be the object of another collateral work with continuous pressure transducers monitoring water table levels. During the years, REMA's (Ressacada Environmental Research Group) technicians directly measured the depths of the water table with a manual phreatimeter. Subsequently, raw data were converted to absolute hydraulic head above mean sea level (zero reference was at the ground control point of Imbituba - Nation Sea Level Station) and converted to millimeters. The justification of the unit is linked to the accuracy of the manual phreatimeter and the resolution of the values in the rainfall data series.
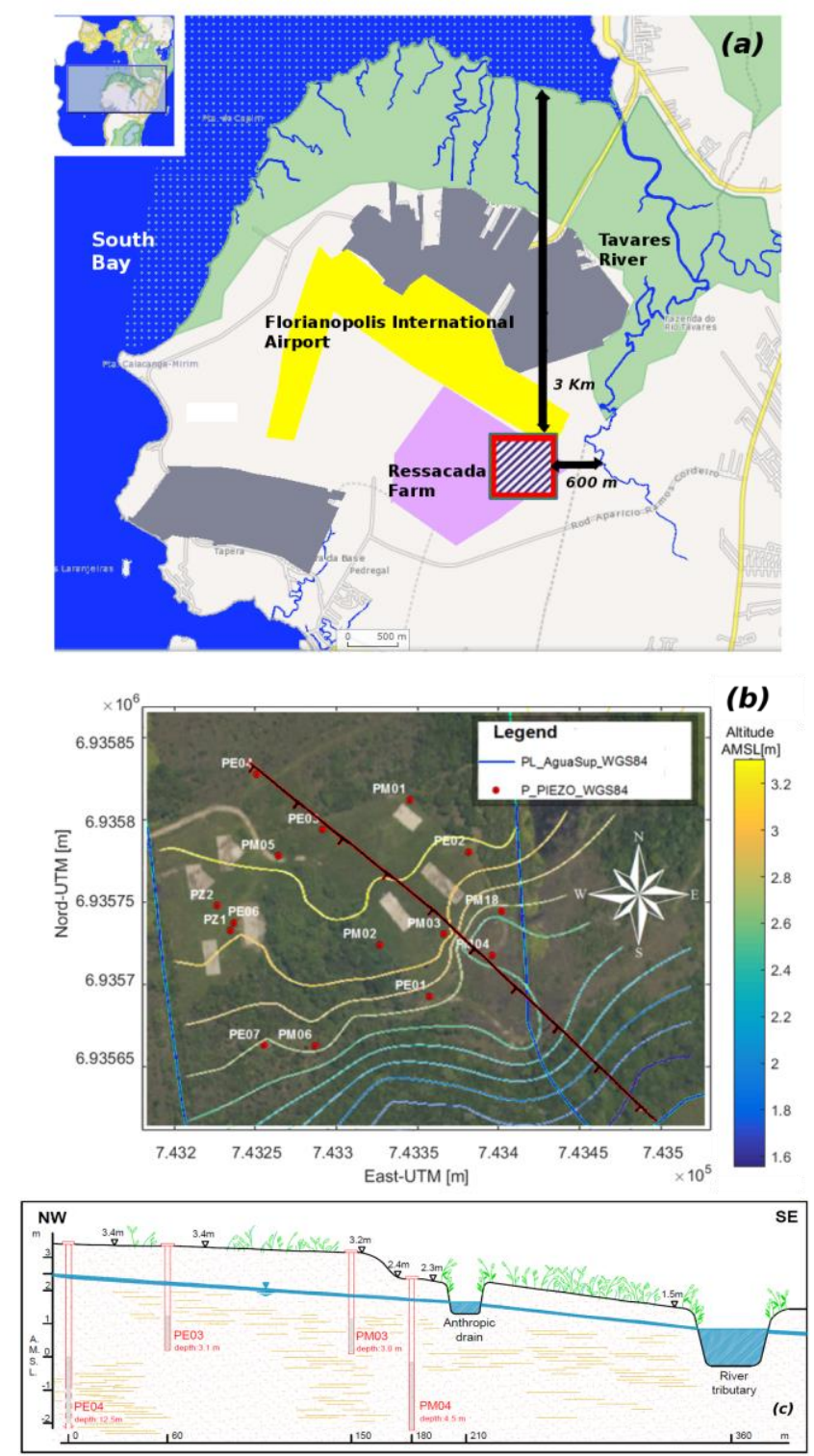

Fig. 1. Geographical position of the Ressacada Farm (a) and location of experimental area (dashed square area). Overlapping contour lines on the aerial photo show the topography in the Experimental Area3 (b) and black vertical line indicates longitudinal section. Coordinates refer to WGS $1984-$ UTM 22S. Schematic hydrogeological sketch (c). 
TABLE I: DETAILS OF PIEZOMETERS INCLUDED IN THE STUDY

\begin{tabular}{cccc}
\hline \hline $\begin{array}{c}\text { Name } \\
\text { Ref. Code) }\end{array}$ & $\begin{array}{c}\text { Ground altitude } \\
\text { AMSL }[\mathrm{m}]\end{array}$ & $\begin{array}{c}\text { Well screen depth } \\
\text { (top/bottom) }[\mathrm{m}]\end{array}$ & $\begin{array}{c}\text { Well case } \\
\text { diameter [cm] }\end{array}$ \\
\hline PE01 & 2.83 & $2.5 / 4.5$ & 5.08 \\
PE02 & 3.20 & $2.5 / 4.5$ & 5.08 \\
PE03 & 3.30 & $2.5 / 4.5$ & 5.08 \\
PE06 & 3.10 & $20.0 / 30.0$ & 10.16 \\
PE07 & 2.72 & $11.0 / 13.0$ & 11.43 \\
PM01 & 3.32 & $2.5 / 4.5$ & 5.08 \\
PM02 & 3.25 & $2.5 / 4.5$ & 5.08 \\
PM04 & 2.50 & $2.5 / 4.5$ & 5.08 \\
PM05 & 3.32 & $2.5 / 4.5$ & 5.08 \\
PM06 & 2.88 & $2.0 / 4.0$ & 5.08 \\
PM18 & 2.66 & $1.0 / 3.0$ & 5.08 \\
PZ01 & 3.12 & $10.0 / 15.0$ & 5.08 \\
PZ02 & 3.19 & $5.0 / 10.0$ & 5.08 \\
\hline \hline
\end{tabular}

Starting from the hydraulic head, the following values were defined and estimated in every sampling interval: the water levels between consecutive measurements [mm], the sampling interval between these measurements [days] and the changing level rate $[\mathrm{mm} / \mathrm{d}]$ like the ratio between differenced levels and sampling interval. Cumulative rainfall was also calculated in every sampling interval $[\mathrm{mm}]$, as the sum of the precipitations falling between the first day of the interval (included) until the second day of the interval (excluded), and then the uniform cumulated rainfall as ratio between cumulative rainfalls and sampling intervals [mm/day]. After that, the intervals with null accumulated precipitation were isolated and used to determine the only rates related to the drainage processes (defined $\mathrm{D}$ in the paper) where no recharge forcing occurs. As evidenced in [12], the $\mathrm{D}$ value in the application of time-series approach of the WTF method simplifies, in a "scalar" term, all the water level decreases, which are concomitant, and mostly nonlinear natural processes (evaporation, transpiration, lateral drainage). Far from wanting to provide an indepth explanation of the cited phenomena, the D parameter is designed to help interpreting natural water table trends and dynamics in an area. The drainage rate, although it is a simplification, provides useful and statistically based information by interpreting the dynamics of an aquifer. It is important to highlight that the choice of working with uniform (daily) rates bypasses the large variability in the sampling intervals, allowing spatial and temporal comparisons of measurements.

The authors underline that only the rates in 2 to 7 days of sampling intervals were included in the statistical analysis of drainage term. The upper limit of 7 days was indeed the maximum interval found in the $\mathrm{D}$ rates but this agrees with [11] for whom intervals longer than weekly between level data could cause unacceptable underestimations of recharges with the application of WTF. On the other hand, when discarding 1 day spaced data the high amount of noise present in the close-range measurements was significant. This fact depends on the intrinsic limits of discrete precipitation data - cumulated on a daily basis - to explain long-term and continuous phenomena (infiltration and recharge). Therefore, because we could not guarantee the independence of drainage rate from a precipitation prior to the 1-day interval, it was preferred to exclude such data. To verify such a choice, the sample interval distributions (probability density function PDF and cumulative distribution function CDF) were studied for each well (resulting lognormal with median in 4 , mean in 4.5 and mode in 3 days). The histograms showed that more than $75 \%$ of the data fell within 2 to 4 days and that, by taking out the other intervals, the dataset would have lost approximately $10 \%$ of the data: a value considered acceptable given the high number of measurements ( 800 per piezometer).
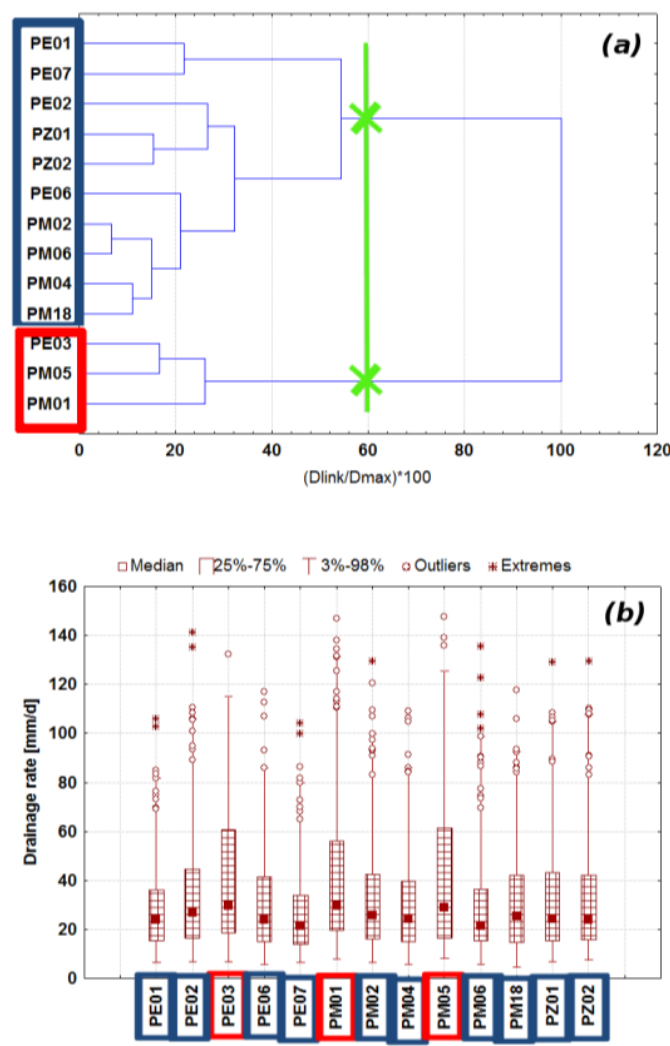

Fig. 2. Dendrogram resulting from cluster analysis of piezometers with consolidated hypothesis of clustering reported in green (a). Box plots of piezometers D rates: group1 in blue and group2 in red (b).

The methodology used for analyzing data is based on classical statistical tools: univariate and bivariate statistics were used focusing on the descriptive analysis of the raw head data collected and the drainage rates estimated. First of all position parameters (expected value, median, mode), dispersion (range, standard deviation, quartiles) and data deformation (skewness and kurtosis) were estimated. Then, extreme values and signalized outliers were studied to determine whether to include them or not in the analysis. The next step was to establish discrete histograms and theoretical distributions. Finally, variability in time and space was thoroughly investigated, analyzing the possible presence of different populations in the data. For this exercise, the characteristics of the region were linked to the statistical elaborations with an understanding of the physical part and the dynamics in action in the subsoil. The characteristics of the area, the proximity to the mangrove swamp and the reduced distance from the boundary receptors (approximately $3 \mathrm{~km}$ from the South Bay, $2 \mathrm{~km}$ from the Ribeirão Bay and less than $500 \mathrm{~m}$ from the Tavares River) have a direct influence on surface and groundwater drainage of the region and, therefore, in the statistical response of the aquifer to the rainfalls. 


\section{RESULTS}

A univariate analysis of raw data was performed to explain their distributions: the histograms of hydraulic head for every piezometer showed gaussian distributions, as opposite to drainage rates that were markedly lognormal. Furthermore, we remark that the drainage term was initially convert in a positive term using the absolute value (all negatives). Following on with descriptive analysis of drainage data organized by piezometer, we found medians between 21 and $27 \mathrm{~mm} / \mathrm{d}$, mean of 26.3 to $36.6 \mathrm{~mm} / \mathrm{d}$ with an error of $2 \mathrm{~mm} / \mathrm{d}$ and standard deviations of 18.6 to $24.8 \mathrm{~mm} / \mathrm{d}$. Therefore, for an effective and synthetic presentation of the data box-plots were used with a central mark indicating the median, the bottom and top edges of the box indicating the $25^{\text {th }}$ and $75^{\text {th }}$ percentiles and two whiskers reaching the $2.5 \%$ percentiles.

\begin{tabular}{llll}
\multicolumn{4}{c}{ TABLE II: DESCRIPTIVE STATISTICS } \\
\hline & $\begin{array}{l}\text { Raw Levels } \\
\text { AMSL [mm] }\end{array}$ & $\begin{array}{l}\text { D (Group1) } \\
{[\mathrm{mm} / \mathrm{d}]}\end{array}$ & $\begin{array}{l}\text { D (Group2) } \\
{[\mathrm{mm} / \mathrm{d}]}\end{array}$ \\
\hline Cases (N) & 10904 & 1699 & 546 \\
Mean & $1690.5 \pm 10.3$ & $31 \pm 0.6$ & $41.5 \pm 1.3$ \\
C.I. Mean (95\%) & $1673.5 / 1707.5$ & $30.1 / 31.9$ & $39.3 / 43.7$ \\
Median & 1676.5 & 24 & 29.5 \\
Stand.Dev. (SD) & 279.7 & 22.9 & 31.4 \\
C.I. SD (95\%) & $266.1 / 294.7$ & $22.2 / 23.7$ & $29.7 / 33.4$ \\
Mín & 865.0 & 1.7 & 2.7 \\
Máx & 2905.0 & 141.0 & 147.5 \\
Quartil (25\%) & 1505.5 & 15.4 & 18 \\
Quartil (75\%) & 1873.2 & 39.7 & 59.3 \\
Skewness & $0.2 \pm 0.1$ & $1.7 \pm 0.1$ & $1.2 \pm 0.1$ \\
Kurtosis & $-0.1 \pm 0.2$ & $2.9 \pm 0.1$ & $0.7 \pm 0.2$ \\
\hline \hline
\end{tabular}

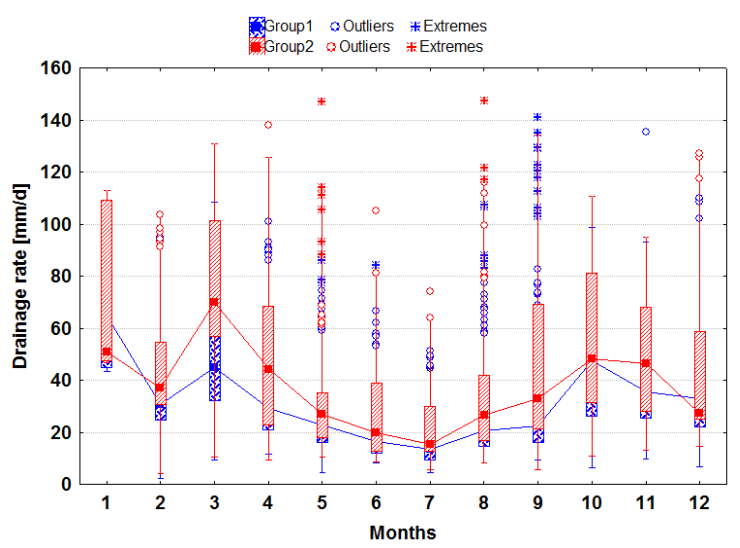

Fig. 3. Box plot of drainage-by-month to study the seasonality. Note the large amount of extreme values and outliers also in months with less average rains.

In these initial stages all the series were consolidated, analyzing suspect outliers and extreme values to fix them and a clustering analysis was performed with the log transformed drainage series and consecutively, with CDFs, using both the complete linkage and the Ward's method (as in Fig.2). The aim was to identify possibly different population of response of the water level. All the methods converged to similar cluster results, indicating the reliability of the procedure. By having two clustering hypothesis, an analysis of variance (ANOVA) was applied to statistically consolidate the assumptions of two groups instead of three. Then, a physical-based connection between the groups and the variation of hydraulic conductivity was sought (a slug test campaign was performed on all 13 piezometers and interpreted with Winslug® software in December 2016), but it was not possible to consolidate this relationship. Although Group2 $(6.16 \mathrm{E}-04 \mathrm{~cm} / \mathrm{s})$ has a lower average conductivity than Group1 (3.37E-03 cm/s), Group 1 also includes low conductivity piezometers (e.g. PE07). The conductivity estimation was performed with both Bower-Rice and Hvorslev method, choosing the first one for reported values of hydraulic conductivities.

On the other hand, it was underlined that clustering could be related to the altitude of the ground (topography). Therefore, drainage rate series can be aggregated based on the well position in the groundwater flow field and, in particular, by distance to surface receptors that drain the area. In accordance with this idea, Group 1 includes all the piezometers downstream along the main flow direction and Group 2 includes just three "high" piezometers upgradient in the area (as shown in Fig.1). In this simplified description, it is important to highlight the presence of a transition group of piezometers in the middle area, between the high area and down area (e.g. PE02 and PM02).

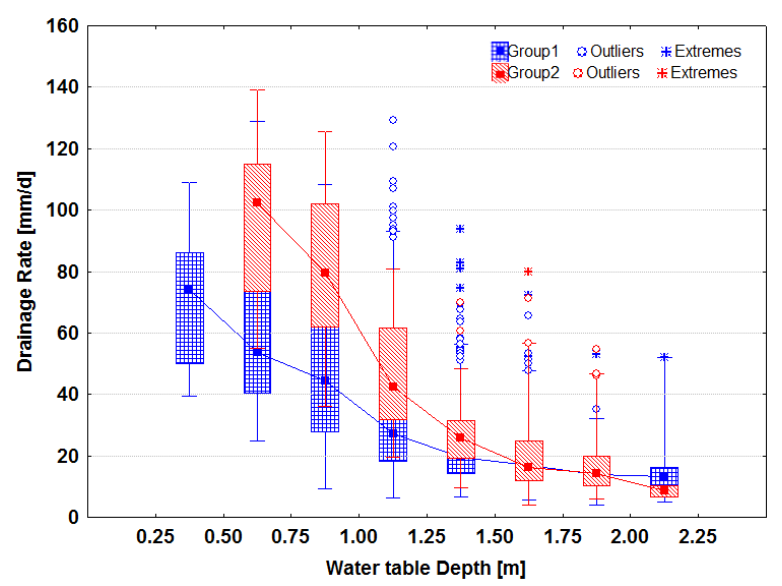

Fig. 4. Box plot of drainage-by-depth in each group of piezometers.

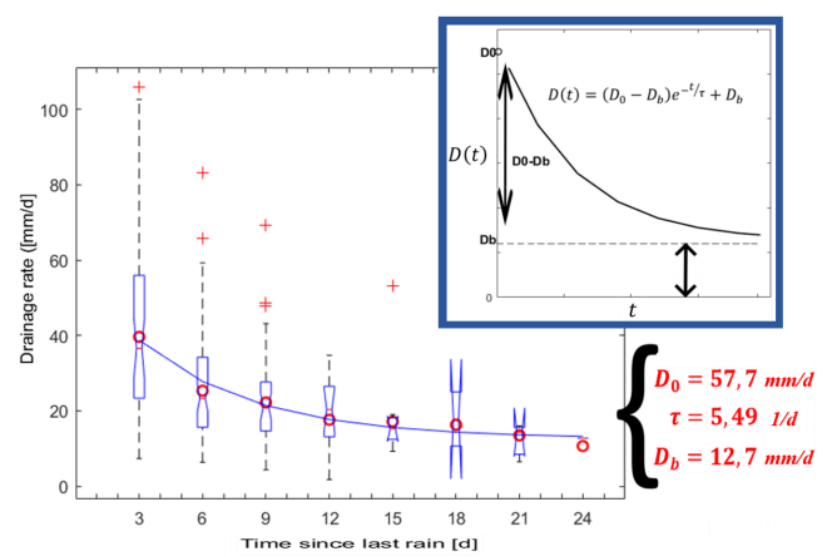

Fig. 5. Box plot of D rates organized by time since last rain; the exponential model built on this formulation and best fit coefficients for whole D dataset (all piezometers of the experimental area studied together).

For the subsequent statistical analysis, these transition piezometers, with intermediary features, were aggregated in the first group (Fig. 2). Nevertheless we have to point out that in some cases their behavior was closer to the piezometers of Group 2. For example, their good compliance in the spatial analysis of basal and initial drainage will be analyzed in Fig. 8 . This ambiguity can be explained by the proximity between the two groups and the mild topography of the experimental area: elevation distance between higher and lower 
piezometer is approximately $1 \mathrm{~m}$. By translating these clustering results into a hydrodynamic conceptual model, we could say that the main forcing of natural flow in the whole domain is rain infiltration (relevant direction NW-SE), which is stored in the higher central area of the Farm, and is regulated by the hydraulic head of the downstream water bodies or receptors: the farthest piezometers from the receptor bodies also appear the most sensitive with rainfall showing larger fluctuations and faster rates of decrease. The broader ranges in the D-rates (Table II) and the greater depths reached by the groundwater in Group 2 seem to confirm this hypothesis.

In the following stage, drainage trends in the two groups were studied by seasonality and as a function of water table conditions or distance from the last precipitation.

$$
\min _{x}\|F(b, t)-D\|_{2}^{2}=\min _{x} \sum_{i}\left(F\left(b, t_{i}\right)-D_{i}\right)^{2}
$$

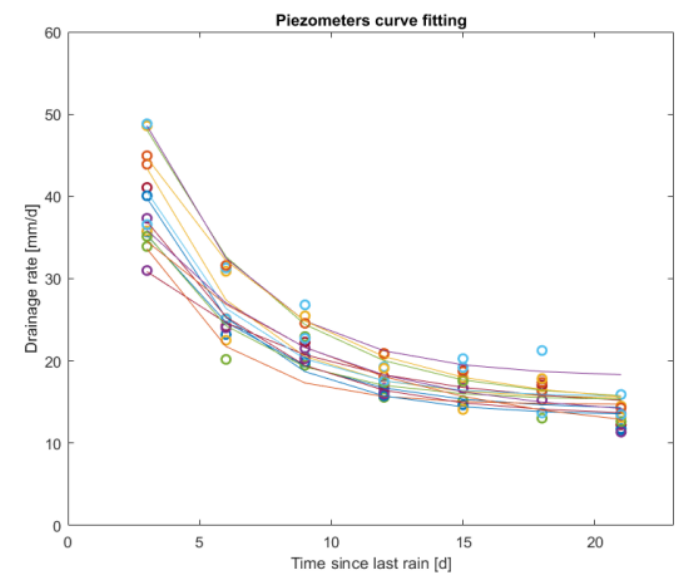

Fig. 6. Piezometers best fitting curves on geometric mean values at each time step (found applying the exponential model built previously).

Fig. 3 shows drainage rates of the groups of piezometers organized per month. This graph shows no temporal or seasonal trend: the spikes in the months of January, March, October and November (months of intense rains and in average much higher decrease rates) do not prevent the presence of extreme values in other months, in conjunction with isolated rains.

Fig. 4 presents drainage rates organized by depth to water table and shows, in the case of water level up to 1 meter deep, a drainage 4 or 5 times greater respect to basic. This seems like a head-dependent relationship, as would be expected by Darcy's Law. In addition, decrease rates seem to reach, at the limit, a horizontal asymptote value similar for both groups, a sort of common basal drainage in the area. As was expected, his fact suggests a "quasi-steady" groundwater flow in equilibrium with the hydraulic head in surface receptors (anthropic drain and river), which rapidly passed to be regulated by the intense increase in aquifer level during rainfall events. By increasing the hydraulic head, a flow with a larger hydraulic gradient and consistent vertical components is activated and on average exhausts within a maximum of 5 days, coming back to basal drainage rate.

Finally, but yet importantly, Fig.5 shows drainage box plots organized by time since the last rain. It was observed that the decrease rates had on average higher values soon after the precipitations ended. This fact indicated the possibility of designing an exponential model to explain drainage term against time by fitting a curve above the central position of every box (as they were lognormal distributions, the geometric means was used as central position).
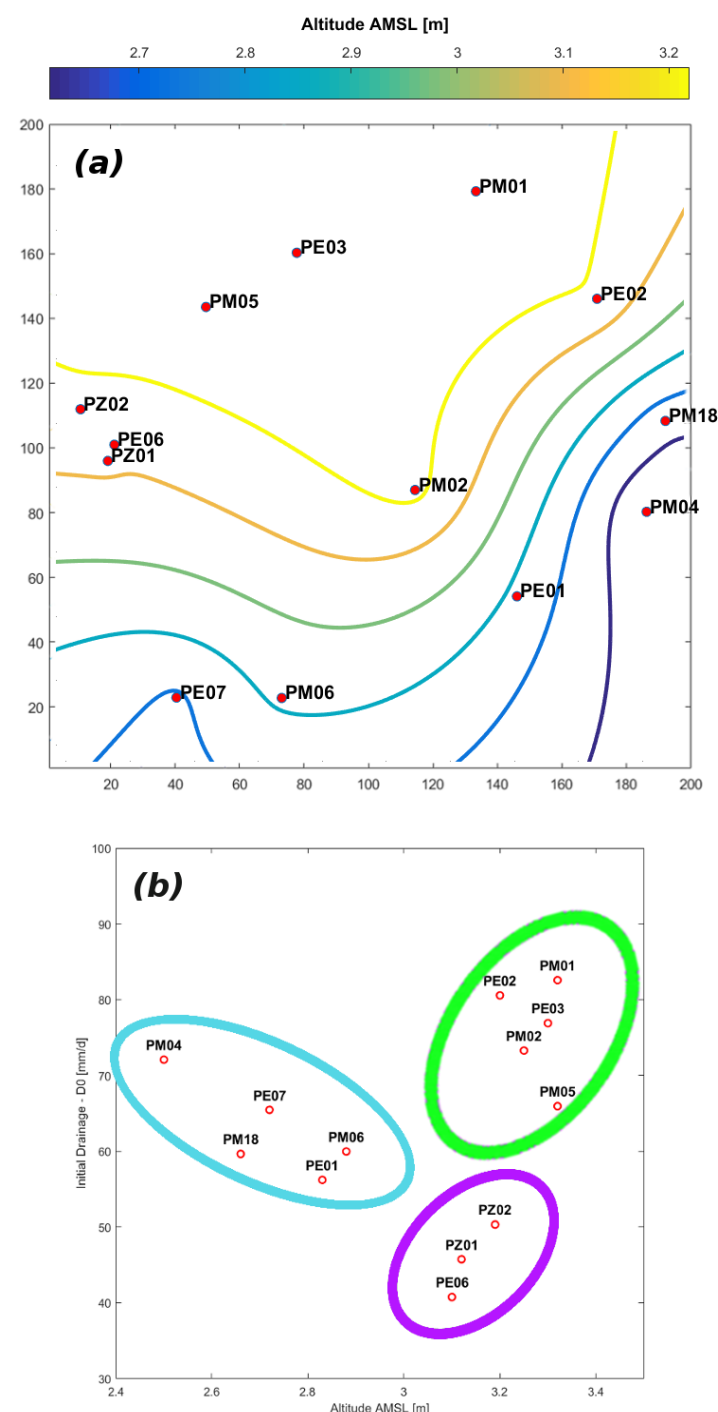

Fig. 7. Altitude contour plot (a) of $200 \times 200 \mathrm{~m}$ area with the origin in 743215E-6935653N (Coordinates was in GCS WGS 1984 - UTM 22S). Scatter plot of $\mathrm{D}_{0}$ against the altitude of point (b) confirms a clustering trend by position: higher piezometers (light green), piezometers in the lower plain (light blue), low but also deep piezometers (purple).

Through the optimization of the fitting process it was possible to identify, for the whole area and for every piezometer: a basal drainage rate $\left(D_{b}\right)[\mathrm{mm} / \mathrm{d}]$ as the residual drainage when the rainfall perturbation was shrunk, an Y-intercept of the curve which represents initial rate of decrease after the precipitation event $\left(\mathrm{D}_{0}\right)[\mathrm{mm} / \mathrm{d}]$ and a decay coefficient associated with the perturbation depletion time $(\tau)[1 / \mathrm{d}]$. Two algorithms were tested to optimize the fitting process: one that solved nonlinear data-fitting problems in least-squares sense, as in (1), and the other, a robust bisquare fitting that minimizes a weighted sum of squares, where the weight is given depending on how far the point is from the fitted line. The algorithm chosen for fitting our data was the first one, because every point in the data was the central position of distribution already. For this reason we chose a curve that fits the bulk of the data using the usual least-squares approach, without having to minimize the effect 
of outliers (common in broad dataset but secondary in this case). Therefore, for every piezometer, were found in (1) a vector $b$ of exponential function coefficients $\left(D_{0}, 1 / \tau\right.$ and $\left.D_{b}\right)$ that solve the nonlinear fitting problem (Fig. 6), given input data $\mathrm{t}$ (chosen time steps) and the observed output $\mathrm{D}$ (geometric mean of drainage rates at each step). In the next part of the discussion, we will emphasize the spatial variability of these drainage coefficients.

Regarding the relation between initial decrease rates $\left(D_{0}\right)$ and elevation of the ground, Fig. 7 confirms that the groundwater flows from the "high" zone with more intense decrease rates to "low" area with a less sharp decrease profile. In this sense, PM04 and PM18 represent an exception since follow an inverse trend; these piezometers, in fact, are located near the final receptors (anthropic drain), in the ideal downstream closure sections of groundwater flow. Based on the results, it was observed that the relation of $\mathrm{D}_{0}$ against elevation loses intensity on the lower part of the area, probably due to the proximity between the plain and the morass area near the river. In addition, Fig. 7 shows a sort of aggregation trend by piezometer position, partially corroborating cluster analysis. Regarding this matter, it should be noted the aggregation of PM02 and PE02 to the light green group, due to the proximity between the piezometers.

At this step, we were able to design a spatial analysis of the three-coefficient vector $b$, which was described in Fig.8. The results confirmed once again the cluster analysis indications and the assumption of an altitude-based cluster. Both contour plots $\left(D_{b}\right.$ and $D_{0}$ in Fig.8), showed higher values of drainage near PM1, PE03 and PE02, that was the highest area in accordance with elevation contours (Fig.7). Nevertheless, the ranges of drainage were consistently different in the two plots: $\mathrm{D}_{0}$ showed a wide range of values while $\mathrm{D}_{\mathrm{b}}$ values were similar in the whole area. In addition, it should be noted that $\mathrm{D}_{\mathrm{b}}$ values for piezometers were close to the basal drainage for whole area $(12.7 \mathrm{~mm} / \mathrm{d})$ and to the limit values found with drainage-by-depth box plots (Fig. 4).

For this reason, $\mathrm{D}_{\mathrm{b}}$ can be considered approximately constant in the area and just linked with receptors hydraulic head. On the other hand, contour lines of $80 \%$ decay time showed a similar behavior between the most of piezometers with an approximately constant value of 1 to 1.2 days to attenuate $80 \%$ of initial drainage perturbation. An exception of this line of evidence was represented by "deep" piezometers (PE06, PZ01, and PZ02) that showed an attenuation time more than twice the others. About this fact, three hypothesis could be raised: 1) the influence of a sharp variation in the geology due to a less conductive layer in that area; 2 ) the presence of a multi-layered aquifer system, only intercepted and highlighted by deep piezometers; 3) a leakage from the upgradient anthropic drain that recharges and sustains the local flow during the drainage phase. Spatial distribution of $D_{0}$ and $D_{b}$ in Fig.8 seem to corroborate one of these assumptions.

For each group of piezometers, the study of the spatial and temporal variability in the drainage rates suggested the presence of two data populations in terms of time-elapsed since the last rainfall (depending by hydraulic head). In order to consolidate this hypothesis, another ANOVA was applied to the four cases identified.
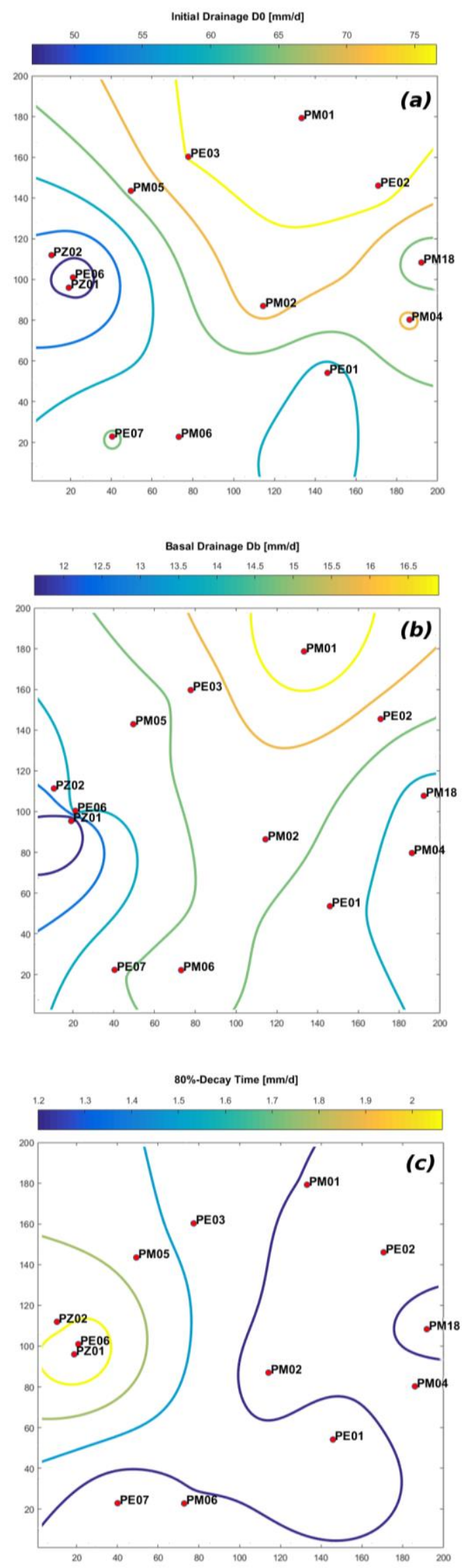

Fig. 8. Contour line maps of spatial variation of coefficient: $D_{0}(a), D_{b}(b)$ and $80 \%$ decay perturbation time (c). The $200 \times 200 \mathrm{~m}$ grid area has the origin in 743215E-6935653N (Coordinates was in GCS WGS 1984 - UTM 22S)

Defining typical values of drainage for each condition: "Case A" was Group1 of piezometers when the depth of the 
water table was up to $1 \mathrm{~m}$, "Case B" was Group2 in the same condition, "Case C" was the Group1 with water head below 1 $m$ depth and "Case D" was Group2 in this same condition. In the Fig. 9 cases A and B, which represent a high water head condition, shown a considerable distance between the means, which was much more consistent with respect to "low" water table condition (cases $\mathrm{C}$ and D). This fact copper-fastened what was highlighted in the whole analysis: the presence of a similar basal drainage $\left(D_{b}\right)$ for all piezometers and conditions, which represent an equilibrium flow field regulated by the receptors water level. The final step defined a reference value of drainage in each of four conditions, estimated from the median values of anti-transformed distribution (orange table in Fig. 9).
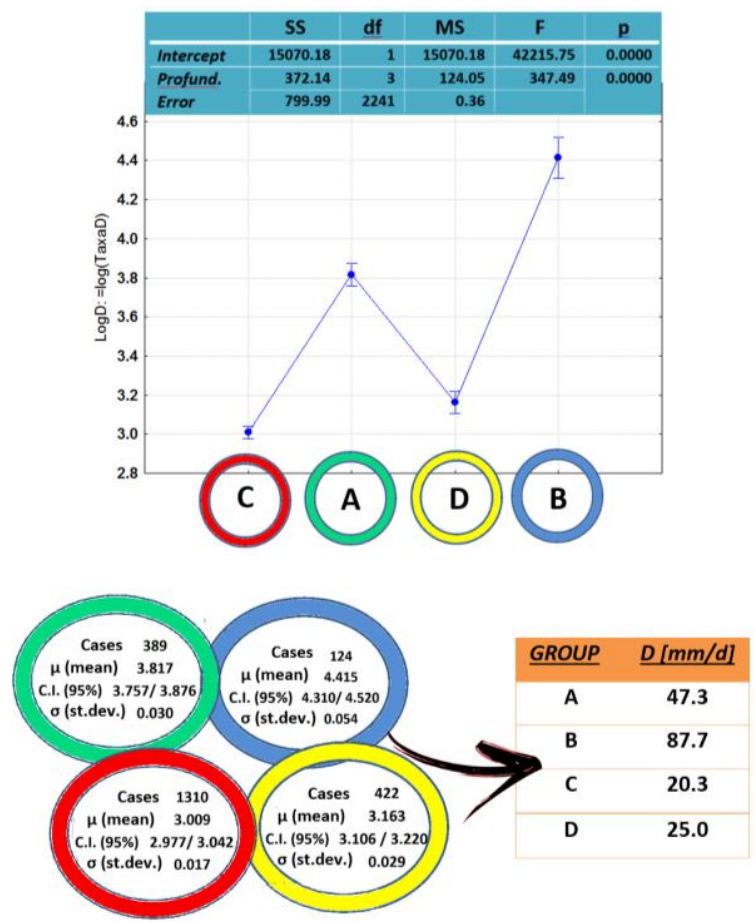

Fig. 9. Results of ANOVA and inference of centered statistically-based typical values for drainage in the Ressacada aquifer.

\section{CONCLUSION}

A main result of the study was to build an exponential model for the drainage rates in the timeframe, highlighting typical mean values of basal drainage and initial rate of decrease after the rain event for the whole area (Fig. 5). This approach made the big difference between these two values evident. A subsequent spatial analysis of the coefficients allowed the investigation of the relations between the piezometers. Due to the high variability in time and space found for the drainage term in the Ressacada Farm, differentiated values were assumed. These values represent specific aquifer conditions related with the time elapsed since the last rain or with hydraulic head of water table. In making this choice the authors diverged from a single drainage option of [12].

The statistically-based approach of the study allowed the consolidation of two groups of piezometers diverging for elevation and behavior. These findings, in addition of the two aforementioned aquifer conditions, determined four typical values for the drainage term in the Ressacada Farm. Mean values were defined as a function of the position of the piezometers and the aquifer hydraulic head, and represent specific water table conditions. In the "quasi-steady" conditions (low hydraulic heads or far from the rains), drainage values agreed with other studies in similar coastal areas, confirming the validity of the methodology. On the other hand, the underlined high values of cases A and B (high water table head condition) emphasized the importance of a reliable estimation of the drainage term in the periods of intense rains, for an accurate application of the WTF method in such subtropical area.

Through the aforementioned steps, a comprehensive study of water table decrease rates in the Ressacada was built, achieving the aim of the paper. Therefore, depending on the accuracy of the recharge estimation we have to achieve, it is now possible to use in the WTF method one of several drainage values found within the study (single mean values for the whole area, groups values or piezometers values).

\section{REFERENCES}

[1] D. C. Neto, H. K. Chang, and M. T. van Genuchten, "A mathematica view of water table fluctuations in a shallow aquifer in Brazil," Groundwater, vol. 54, no. 1, pp. 82-91, 2016.

[2] X. Mao, P. Enot, D. A. Barry, L. Li, A. Binley, and D. S. Jeng, "Tidal influence on behaviour of a coastal aquifer adjacent to a low-relief estuary," J. Hydrol., vol. 327, no. 1-2, pp. 110-127, 2006.

[3] B. Ataie-Ashtiani, R. E. Volker, and D. A. Lockington, "Tidal effects on groundwater dynamics in unconfined aquifers," Hydrol. Process., vol. 15, no. 4, pp. 655-669, 2001.

[4] C. E. Braga, I. D. C. Lage, G. Cardoso, and A. F. Damasceno, "O Comportamento Hidroquímico E Hidrodinâmico De Aqüífero Sob Influência Do Efeito-Maré," in XII Congresso Brasileiro de Águas Subterrâneas, 2002, pp. 1-12.

[5] I. C. Lage and C. E. Braga, "Caracterização geológica e hidrogeológica de uma área de manguezal em indústria petroquímica," I Simpósio de Hidrogeologia do Sudeste, 2003, pp. 205-216.

[6] D. L. Lorenz and G. N. Delin, "A regression model to estimate regional ground water recharge," Groundwater, vol. 45, no. 2, pp. 196-208, 2007.

[7] M. Masetti, D. Pedretti, A. Sorichetta, S. Stevenazzi, and F. Bacci, "Impact of a storm-water infiltration basin on the recharge dynamics in a highly permeable aquifer," Water Resour. Manag., vol. 30, no. 1, pp. 149-165, 2016.

[8] S. R. Saghravani, I. Yusoff, W. Tahir, and Z. Othman, "Comparison of water table fluctuation and chloride mass balance methods for recharge estimation in a tropical rainforest climate: a case study from Kelantan River catchment, Malaysia," Environ. Earth Sci., vol. 73, no. 8, pp. 4419-4428, 2015

[9] B. R. Scanlon, R. W. Healy, and P. G. Cook, "Choosing appropriate techniques for quantifying groundwater recharge," Hydrogeol. J., vol. 10 , no. 1 , pp. 18-39, 2002.

[10] R. W. Healy and P. G. Cook, "Using groundwater levels to estimate recharge," Hydrogeol. J., vol. 10, no. 1, pp. 91-109, 2002.

[11] G. N. Delin, R. W. Healy, D. L. Lorenz, and J. R. Nimmo, "Comparison of local- to regional-scale estimates of ground-water recharge in Minnesota, USA,” J. Hydrol., vol. 334, no. 1-2, pp. 231-249, 2007.

[12] R. S. Crosbie, P. Binning, and J. D. Kalma, "A time series approach to inferring groundwater recharge using the water table fluctuation method," Water Resour. Res., vol. 41, no. 1, pp. 1-9, 2005.

[13] N. O. Horn Filho, A. D. Schmidt, C. Benedet, J. Neves, L. H. F Pimenta, M. Paquette, and R. Alencar, "Estudo Geológico dos Depósitos Clásticos Quaternários Superficiais da Planície Costeira de Santa Catarina, Brasil," Gravel, pp. 41-107, 2014.

[14] I. de C. Lage, "Avaliação de metodologia para determinação da permeabilidade em meio porosos: Fazenda Ressacada." M.S. thesis, Dept. Geosciences, UFRJ, Rio de Janeiro, Brazil, 2005.

[15] M. C. Peel, B. L. Finlayson, and T. A. McMahon, "Updated world map of the K̈oppen-Geiger climate classification,” Hydrol. Earth Syst. Sci., vol. 15, no. 3, pp. 259-263, 2006.

[16] A. M. Grimm, S. E. T. Ferraz, and J. Gomes, "Precipitation Anomalies in Southern Brazil Associated with El Niño and La Niña Events," $J$. Clim., vol. 11, no. 11, pp. 2863-2880, 1998. 
Fabrizio Rama was born in Rome, Italy on April 5, 1985. He studied at Universitá degli studi di Roma, Sapienza. He had a bachelor (2008) and master (2011) degree in environmental engineering, with focus on hydrology/subsoil issues and low enthalpy geothermal systems, respectively. He had a second-level master (master REA energy) at Centro di Geotecnologie of University of Sienna (2013). Between 2013 and 2014 he was technological promoter for innovation for Edillio Srl $\left(3^{\text {rd }}\right.$ edition winner project of "Technological Innovation Promoters" call for proposals of Provincia di Roma) and subsoil assistant manager for Hydroingea Srl. He is now with the Department of Environmental Engineering at Federal University of Santa Catarina (UFSC), Florianopolis, Brazil, in the last year of $\mathrm{Ph} . \mathrm{D}$. course. His research focus on groundwater flow FEM modelling and transport of solute plumes.

Davide Franco had a degree in electronic engineering at Universita degli Studi di Padova (1988) and a PhD in chemical sciences at Università degli Studi di Venezia (1992). He is currently assistant professor III with the Department of Environmental Engineering, Federal University of Santa
Catarina and supervisor in the laboratory of Hidraulica Maritima (Lahimar) $\mathrm{He}$ has experience in the area of oceanography with emphasis in physica oceanography and ecology, working mainly on the following topics: coastal hydrodynamics, coastal ecosystems, statistical modeling and numerical modeling.

Henry X. Corseuil had a degree in civil engineering at Federal University of Santa Maria (1980), a master in water resources and environmental sanitation at Federal University of Rio Grande do Sul (1984) and a PhD in environmental engineering, University of Michigan (1992). He is currently a consultant for Petróleo Brasileiro (Rio de Janeiro-Matriz), "1d" researcher at the National Council for Scientific and Technological Development and a full professor at the Federal University of Santa Catarina. He has experience in sanitation engineering, with emphasis on remediation of soils and groundwater, working mainly on the following topics: impacted areas, groundwater, bioremediation of gasoline/ethanol mixtures and diesel/biodiesel. 